\title{
Následky porušení povinností ze smlouvy o výkonu funkce a jejich vymáhání: limity odpovědnosti člena orgánu a limity smlouvy o vypořádání
}

\section{Consequences of the Breach of Management Contract and its Enforcement: Restricting of the Responsibility of a Member of Business Corporation's Body and the Limits of the Agreement on the Settlement}

Monika Př́kazská*

\begin{abstract}
Abstrakt
Přsspèvek se zabývá omez̨ením odpovédnosti člena orgánu, a to jak odpovédnosti za rádný výkon funkce, tak i odpovédnosti za üjmu, která vanikela v disledku porušeni péce rádného hospodáre. Z pobledu vyporádací

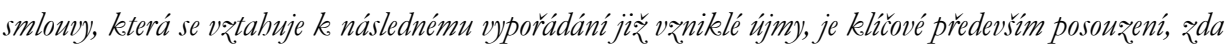
na obsah vyporádaci smlouvy dopadá \2898 OZ (a zda je tedy možné i vyporádáni ve formè úplného prominuti dlubu). A pokud $\int 2898$ OZ zpiisob vyporádání neomezuje, existují patrnè jiné limity vájémného

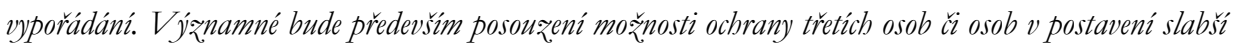
strany, kterých se vyporádaci smlouva uzavrená mezi členem orgánu a obchodni korporaci miř̀ze dotknout.
\end{abstract}

Klíčová slova

Péce rádnébo hospodáre; prominuti dlubu; smlouva o vyporádáni; vyporádaci smlouva; vadáni se práva na nábradu újmy.

\section{Abstract}

A member of a business corporation's body is responsible both for the due execution of his function and for the damages caused by a breach of the duty of care and of the duty of loyalty. The purpose of this paper is to examine the restriction of such responsibility by a way of an agreement on the settlement, which is connected with a damage already suffered. When restricting responsibility by such an agreement, the crucial issue is whether the agreement is covered by the Art. 2898 of the Civil Code and thus settling damages by waiving the whole debt is possible at all. Even if it is the case that the manner of the settlement is not limited by the Art. 2898 of the Civil Code, other restrictions to a reciprocal settlement may apply. It is thus especially important to establish whether there is a possibility of a protection of third parties or of persons in a weaker position, because it is these persons whom a settlement agreement concluded between a member of a body and a company would affect.

Keywords

Duty of Care and Duty of Loyalty; Waiver of the Debt; Agreement on the Settlement; Settlement Agreement; Waiver of Damages.

\footnotetext{
Mgr. Monika Př́ikazská, Katedra obchodního práva, Právnická fakulta, Masarykova univerzita, Brno / Department of Commercial Law, Faculty of Law, Masaryk University, Brno, Czech Republic / E-mail: monika.prikazska@law.muni.cz
} 


\section{Úvod}

V literatuře se diskutují limity vypořádání mezi členem orgánu obchodní korporace a obchodní korporací, které plynou z porušení péče řádného hospodáře, resp. z porušení povinností plynoucích ze smlouvy o výkonu funkce. Text níže navazuje na odborné diskuze a hledá limity odpovědnosti člena orgánu a vzájemného vypořádání mezi členem orgánu a touto obchodní korporací. Následně předkládá přehled jednotlivých omezení, která se mohou na obsah vypořádací smlouvy vztahovat.

\section{Obecně k porušení povinností ze smlouvy o výkonu funkce}

Smlouva o výkonu funkce konkretizuje obsah závazku mezi obchodní korporací a členem orgánu obchodní korporace. Základní obsah závazku však vyplývá př́imo ze zákona. Nejvýznamnější specifickou povinností, k níž člena orgánu zavazuje přímo zákon, je povinnost jednat s péčí řádného hospodáře.

Některé povinnosti člena orgánu mohou být ve smlouvě o výkonu funkce ještě zdůrazněny. I povinnosti smluvně sjednané (které jdou nad rámec právní úpravy) lze nicméně většinou chápat jako součást péče řádného hospodáře - typicky se jedná o povinnost mlčenlivosti, která spadá pod složku loajality péče řádného hospodáře. V zásadě lze proto zobecnit, že porušení povinností plynoucích ze smlouvy o výkonu funkce lze ve většině prrípadů podřadit pod porušení péče řádného hospodáře. Pokud tedy vznikne obchodní korporaci v souvislosti s porušením povinností plynoucích ze smlouvy o výkonu funkce újma, půjde převážně o situace, kdy člen orgánu současně porušil péči řádného hospodáře.

Zvláštním nástrojem, který mưže účinně vyřešit újmu vzniklou na straně korporace, je smlouva o vzájemném vypořádání (dále také jen „vypořádací smlouva“) podle \53 odst. 3 zákona č. 90/2012 Sb., o obchodních společnostech a družstvech (zákon o obchodních korporacích; dále jen „ZOK“ nebo „zákon o obchodních korporacích“). V praxi se může jednat o významný nástroj vzájemného urovnání právních poměrů mezi členem orgánu a obchodní korporací. Vypořádací smlouva představuje čistě soukromoprávní institut, k jehož uplatnění - na rozdíl od řady jiných - není třeba zásahu ani součinnosti soudní moci. Z hlediska soukromoprávního se jedná o optimální nástroj vzájemného vypořádání a zejména následného vymáhání nároků obchodní korporace vůči členovi orgánu. Ustanovení \53 odst. 3 ZOK ovšem nezůstává bez výkladových obtíží.

\section{Dosavadní pohled na vypořádací smlouvu podle $\$ 53$ odst. 3 ZOK}

Ustanovení \53 odst. 3 ZOK umožňuje vyrovnat újmu, která obchodní korporaci vznikla v důsledku porušení péče řádného hospodáře člena jejího orgánu. ${ }^{1}$

1 S ohledem na omezený rozsah i praktické souvislosti se prríspěvek soustředí pouze na vypořádání v poměrech kapitálových společností. 
Při výkladu \53 odst. 3 ZOK je třeba vycházet především z \53 odst. 2 ZOK a dále z \2898 zákona č. 89/2012 Sb., občanský zákoník (dále jen „OZ“ nebo „občanský zákoník“'). Literatura se shoduje na závěru, že odpovědnost člena orgánu a v zásadě ani náhradu újmy způsobenou porušením péče řádného hospodáře není možné omezit ex ante (nicméně argumentace může spočívat jak ve výkladu \2898 OZ², tak v $\int 53$ odst. $2 \mathrm{ZOK}^{3}$ ). Jak se ale právní úprava staví k možnostem vypořádání újmy ex post? Co vše se může skrývat pod pojmem „vypořádání“ člena orgánu s obchodní korporací?

První názorový proud je konkrétnímu obsahu vypořádací smlouvy zcela otevřený. Předpokládá, že vedle jiných způsobů vzájemného vypořádání může obchodní korporace dluh člena orgánu také zcela prominout. ${ }^{4}$

Naproti tomu se však objevuje názor, že úplné prominutí dluhu obecně možné není. ${ }^{5}$ Uvádí se především, že vypořádání není totéž, co prominutí dluhu. Vypořádání v sobě totiž pojmově zahrnuje ekvivalentní vyrovnání. ${ }^{6}$

Odborná diskuze nakonec těžiště sporu přesunula do občanského zákoníku, a to konkrétně k \2898 OZ. Jak se toto ustanovení projeví v poměrech obchodních korporací?

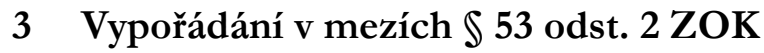

První ustanovení, kterým je třeba se při posuzování limitů vypořádání mezi členem orgánu a obchodní korporací zabývat, je patrně $\int 53$ odst. 2 ZOK. Vypořádací smlouva pojmově zahrnuje vypořádání následné (tedy poté, co již újma vznikla); ustanovení \53 odst. 2 ZOK se naproti tomu týká limitace odpovědnosti za způsobenou újmu ještě před vznikem újmy (nejedná se tedy vlastně o vypořádání, ale spíše o úpravu právních poměrů do budoucna).

Ustanovení \53 odst. 2 ZOK hovoří o nicotnosti ujednání, která omezují odpovědnost člena orgánu. Pojem „omezení odpovědnosti“ v tomto ustanovení můžeme chápat

2 Havel pojímá první větu \2898 OZ jako vyjádření odpovědnosti za řádně plnění. K tomu HAVEL, Bohumil. A ještě k tzv. absolutoriu a také $\mathrm{k}$ přenosu obchodního vedení na správní radu. Obchodněprávní revue, 2013 , roč. 5 , č. 6 , s. 173 .

3 LASÁK, Jan. Komentář k ust. 』53. In: LASÁK, Jan, Jarmila POKORNÁ, Zdeněk ČÁP, Tomáš DOLEŽIL a kol. Zákon o obchodních korporacich. Komentár. I. díl. 1. vyd. Praha: Wolters Kluwer, a. s., 2014, s. 448.

4 PIHERA, Vlastimil. Tvrdé jádro a měkká slupka. Úvaha o odpovědnosti managementu kapitálových společností. Obchodněprávni revue, 2012, roč. 4, č. 5, s. 146; HÁMORSKÁ, Andrea. Povinnost členů orgánů obchodních korporací jednat s péčí řádného hospodáře po rekodifikaci. Obchodněprávní revue, 2012, roč. 4, č. 9 , s. 253 .

5 HAVEL, Bohumil. O kogentnosti, vypořádání újmy a ručení vlivné osoby ve světle nového soukromého práva. Obchodněprávni revue, 2013, roč. 5, č. 1, s. 15; Dále také ŠTENGLOVÁ, Ivana a Bohumil HAVEL. Komentář k ust. \53. In: ŠTENGLOVÁ, Ivana, Bohumil HAVEL, Filip CILEČEK, Petr KUHN a Petr ŠUK. Zákon o obchodních korporacich. Komentár. 1. vyd. Praha: C. H. Beck, 2013, s. 142. Štenglová a Havel zde nicméně také počítají s možnosti, že vypořádat újmu lze i jinak, než jejím plným uhrazením.

6 HAVEL, 2013. O kogentnosti..., op. cit., s. 15. 
v širším smyslu, tedy jako jakoukoliv odpovědnost za cokoliv. Pak by „omezení odpovědnosti“ zahrnovalo jak zákaz jakéhokoliv ujednání omezujícího odpovědnost za řádný výkon práv - v tomto případě výkon funkce člena orgánu, tak i zákaz jakéhokoliv ujednání omezující sekundární odpovědnost k náhradě újmy. ${ }^{7}$

Nicméně jazykové vyjádření tohoto ustanovení je poměrně nezřetelné; pojem „odpovědnost" vyskytující se v \53 odst. 2 ZOK lze vyložit oběma způsoby. Pokud se však budeme držet soudobé koncepce občanského zákoníku, a sice rozlišování odpovědnosti za řádný výkon práv a rozlišování odpovědnosti za náhradu újmy, pak bychom na základě jazykového výkladu dospěli k závěru, že působnost \53 odst. 2 ZOK dopadá spíše pouze na odpovědnost za řádný výkon funkce.

Pak by ale \53 odst. 2 ZOK nemělo stejnou působnost jako \2898 OZ. Zatímco \53 odst. 2 ZOK mírí k odpovědnosti za řádné splnění, ustanovení \2898 OZ i \53 odst. 3 ZOK míŕi již k odpovědnosti za újmu (tedy k navazujícímu právnímu vztahu). Pak ovšem zůstává stranou určitá množina prrípadů, $v$ nichž se obchodní korporace může vzdát náhrady újmy i předem, a to právě v rozsahu, v jakém to dovoluje $\ 2898$ OZ. Tedy např́iklad by se obchodní korporace mohla vzdát předem práva na náhradu újmy, pokud by šlo o újmu zpo̊sobenou v důsledku jiné než hrubé nedbalosti.

I jiná než hrubá nedbalost je však patrně porušením péče řádného hospodáře, resp. pravidlo podnikatelského úsudku se neuplatní, pokud by člen orgánu jednal nedbalostně (at' už hrubě nebo jinak). Vzdání se předem možných nároků na náhradu újmy způsobené jinou než hrubou nedbalostí tak fakticky je také dispozicí se standardem péče ráaného hospodáře (a jejím porušením) - a tedy i omezením odpovědnosti za ráaný výkon podle $\int 53$ odst. 2 ZOK.

I přesto, že jazykový výklad tedy může nasvědčovat jiným závěrům, účelový výklad vede k tomu, že $\int 53$ odst. 2 ZOK zahrnuje nejen omezení odpovědnosti za řádný výkon, ale i omezení deliktní odpovědnosti (předem), jež se s ní pojí.

Ustanovení \53 odst. 2 ZOK se v každém případě vztahuje na právní jednání omezující odpovědnost člena orgánu předem. Dopad na vypořádací smlouvu proto může být pouze nepř́mý a toto ustanovení obsah vypořádací smlouvy nijak neomezuje.

\section{Vypořádání v mezích $\$ 2898 \mathrm{OZ}$}

Podle \ 2898 OZ jsou mimo jiné nicotná taková ujednání, která (vedle dalších) předem vylučují nebo omezují povinnost $\mathrm{k}$ náhradě újmy způsobené úmyslně, z hrubé

7 K takovému výkladu dospívá Lasák, nebot’ závěr o tom, že obchodní korporace se nemůže vzdát práva na náhradu újmy předem, opírá právě o \53 odst. 2 ZOK. LASÁK, Jan. Komentář k ust. \53. In: LASÁK, POKORNÁ, ČÁP, DOLEŽIL a kol., op. cit., s. 448. Stejný názor však také zastává Štenglová a Havel, kteří uvádějí, že $\int 53$ odst. 2 ZOK je přísnější, než \2898 OZ, z čehož lze soudit, že považují jejich působnost za shodnou. ŠTENGLOVÁ, Ivana a Bohumil HAVEL. Komentář k ust. \53. In: ŠTENGLOVÁ, HAVEL, CILEČEK, KUHN, ŠUK, op. cit., s. 142. 
nedbalosti, anebo omezují nebo vylučují toto právo vưči slabší straně. Druhá věta předmětného ustanovení stanoví, že se v těchto prípadech nelze práva na náhradu újmy ani platně vzdát.

Zatímco v př́padě prvního pravidla se jedná o jakékoliv právní jednání a jeho porušení má za následek nicotnost odporujícího ujednání, v druhém př́padě se jedná o jednostranné právní jednání (vzdání se práva), které má za následek „pouze“ případnou neplatnost. Doktrína pochybuje o záměru zákonodárce uplatnit v závislosti na povaze právního jednání odlišnou sankci a nabízí př́ístup, podle něhož se i „,neplatnost“ jednostranného vzdání se práva podle druhé věty v \ 2898 OZ chápe jako nicotnost., ${ }^{8}$

Každopádně však \2898 OZ nevylučuje možnost zprostit škůdce náhrady újmy absolutně - naopak to obecně povoluje a zakazuje pouze taková dvoustranná nebo jednostranná právní jednání, u nichž by v zásadě svolení poškozeného bylo možné chápat jako nemravné či v rozporu s obecným chápáním spravedlnosti.

Ustanovení \2898 OZ se ovšem týká právních jednání, kterými se omezuje náhrada újmy do budoucna. I vzdání se práva ve druhé větě je totiž třeba chápat jako vzdání se předem, nebot' hypotéza druhé věty - „v těchto př̆padech“ je stejná jako hypotéza první věty. ${ }^{10},{ }^{11}$ Pokud se chce poškozený předem vzdát svého práva na náhradu újmy, nemůže tak učinit platně, pokud by byl současně slabší stranou, př́padně pokud by se jednalo o újmu způsobenou hrubou nedbalostí nebo úmyslně.

Následné vypořádání podle \53 odst. 3 ZOK proto podmínky obsažené v \2898 OZ nijak neomezují. Ustanovení \53 odst. 3 ZOK řeší jiný časový okamžik - vypořádací smlouva tak může zahrnovat i ujednání směřující k prominutí dluhu. Možnost vypořádání újmy jejím prominutím může být přitom v praxi v určitých př́padech dokonce vítaná. ${ }^{12}$

Vypořádací smlouva podléhá přezkumu a kontrolním mechanismům uvnitř obchodní korporace. Zákon především podmiňuje její účinnost souhlasem alespoň dvoutřetinové většiny všech společníků korporace. Ke kolektivnímu projevu vưle je tedy třeba

8 Bliže BEZOUŠKA, Petr. Komentáŕ k ust. \2898. In: HULMÁK, Milan a kol. Občanský qákoník VI. Závąkové právo. Zvlástní cást (§ 2055-3014). Komentár. 1. vyd. Praha: C. H. Beck, 2015, s. 1508.

9 Objevuje se však i opačný př́stup. Pokud však chápeme první větu ustanovení $\$ 2898$ OZ jako vyjádření odpovědnosti za řádný výkon (na rozdíl od věty druhé), pak lze vykládat úmysl zákonodárce i tak, že u sekundární odpovědnosti k náhradě újmy bylo jeho záměrem skutečně stanovit ,jen“ neplatnost. Následně je třeba zkoumat, zda se jedná o neplatnost relativní, anebo absolutní. HAVEL, 2013, A ještě..., op. cit., s. 173.

10 PIHERA, 2013, op. cit., s. 76; Následně také BEZOUŠKA, Petr. Komentár k ust. \2898. In: HULMÁK a kol., op. cit., s. 1508.

11 Objevují se i názory opačné - první věta by měla mírit na právní úpravu primární odpovědnosti za řádný výkon práv a druhá věta na právní úpravu sekundární povinnosti $\mathrm{k}$ náhradě újmy. Zejména HAVEL, 2013. A ještě..., op. cit., s. 173.

12 LASÁK, Jan. Komentář k ust. \53. In: LASÁK, POKORNÁ, ČÁP, DOLEŽIL a kol., op. cit., s. 449. 
kvalifikovaná většina (což samo o sobě představuje argument pro závažnost tohoto rozhodnutí, kterým může být i úplné prominutí dluhu odpovídajícímu nároku z odpovědnosti za újmu $)^{13}$. Člena statutárního orgánu, který v zastoupení obchodní korporace vypořádací smlouvu uzavře, váže péče řádného hospodáře. ${ }^{14}$

Případ, kdy společník schvaluje vypořádací smlouvu, kterou má korporace uzavřít s tímtéž společníkem v postavení člena statutárního orgánu, lze při extenzivním výkladu podřadit pod \ 173 odst. 1 písm. c), prípadně pod \ 426 písm. c) ZOK. Rozhoduje se o prominutí povinnosti společníka, byt' tato povinnost plyne z jiného, než společnického vztahu. Hlasovací právo společníka, který je současně v konfliktu zájmů, je tedy sistováno.

\section{Jiné obsahové korektivy vypořádání - hledání hranic}

Pokud \2898 OZ nepředstavuje pro vypořádací smlouvu žádný limit, znamená to, že je smluvní svoboda obchodní korporace a členů jejích orgánů zcela bezbřehá?

Určité limity vypořádací smlouvy plynou z vnitřních kontrolních mechanismů obchodní korporace. Základním nástrojem ochrany (menšinových) společníků je možnost napadnout usnesení valné hromady, které vypořádací smlouvu schválilo. Podle Lasáka může v takovém prípadě odporovat dobrým mravům právě to, že se vypořádává újma, kterou člen orgánu způsobil úmyslně, anebo z hrubé nedbalosti. ${ }^{15} \mathrm{Z}$ tohoto pohledu proto podle jeho názoru může \2898 OZ představovat určité limity pro obsah vypořádací smlouvy. To nás však vede k úvaze, že se \2898 OZ na vypořádací smlouvu fakticky přece jen aplikuje, čímž ale z velké části popíráme předchozí závěry. Nelze se proto asi spokojit s konstatováním, že úmyslné způsobení újmy, případně újma způsobená hrubou nedbalostí člena orgánu může být obecně důvodem, proč namítat neplatnost usnesení s dobrými mravy. Úmysl nebo hrubá nedbalost nezakládají rozpor s dobrými mravy samy o sobě; neplatnost bude třeba opřít ještě o další skutková tvrzení.

$\mathrm{V}$ prvé řadě je třeba vycházet z toho, že i částečné prominutí dluhu bude pro obchodní korporaci vždy z povahy věci v určitém směru nevýhodné. Pokud však bude prominutî dluhu jejím rozhodnutím (projevem kolektivní vůle), jedná se o projev autonomie její vůle. Pouze nevýhodnost tak stěží může být argumentem, proč namítat neplatnost usnesení valné hromady. Určitá nevýhodnost určitě automaticky neznamená nemravnost.

Základním východiskem při hledání hranice smluvní svobody by mohlo být posouzení samotné vypořádací smlouvy jako právního jednání, a to především s ohledem na to,

\footnotetext{
13 Požadavek schválení kvalifikované většiny může být také jedním z argumentů pro závěr, že zákon předpokládá závažnější zpo̊soby vypořádání, než jen stanovení splátkového kalendáře. Ibid., s. 449; Dále také HÁMORSKÁ, op. cit., s. 253.

14 LASÁK, Jan. Komentář k ust. \53. In: LASÁK, POKORNÁ, ČÁP, DOLEŽIL a kol., op. cit., s. 449.

15 Ibid., s. 448 a 450.
} 
zda je vypořádací smlouva skutečně vypořádáním. ${ }^{16}$ Toto posouzení však není možné zužovat pouze na vypořádací smlouvu samotnou. Ekvivalentní vypořádání nemusí být na první pohled vůbec patrné z obsahu samotné vypořádací smlouvy, ale může vyplývat z poměrů v obchodní korporaci či z okolností, které uzavření vypořádací smlouvy provázejí, anebo které lze důvodně očekávat teprve v budoucnu. Lze si představit výjimečné pochybení člena statutárního orgánu (byt' způsobené z hrubé nedbalosti, př́ípadně v důsledku nepřímého úmyslu). $\mathrm{V}$ některých případech se obchodní korporaci vyplatí urovnat s tímto členem orgánu vztahy (i za cenu toho, že dluh plynoucí z nároku na náhradu újmy zcela promine), protože je ve své funkci jen těžko nahraditelný. ${ }^{17}$

Skutečnost, zda se jedná o vypořádání či nikoliv, je proto třeba hodnotit s ohledem na všechny okolnosti a právních poměry v obchodní korporaci. ${ }^{18}$ Tyto okolnosti je možné vtělit i do právního jednání (vypořádací smlouvy) a osvětlit zde důvody, proč se obchodní korporace rozhodla vypořádat újmu právě prominutím dluhu, přičemž všechny tyto úvahy se mohou odrazit i ve výslovně formulovaném účelu smlouvy. Potom by k okolnostem, za nichž člen orgánu a obchodní korporace vypořádací smlouvu uzavřeli, bylo třeba prrihlížet jako k součásti obsahu právního jednání také při jeho výkladu a i noví členové orgánů obchodní korporace by měli právní jednání svých předchůdců hodnotit ve světle těchto zachycených skutečností. ${ }^{19}$

Pokud však nic (ani v širším kontextu) nenasvědčuje tomu, že je vypořádací smlouva přiměřená poměrům, nejedná se vlastně vůbec o vypořádání. Taková vypořádací smlouva je spíše zastřeným právním jednáním, které obchází zákon či které zjevně zneužívá práva ve smyslu \8 OZ.

A právě $\mathrm{v}$ takových případech bude patrně možné domáhat se vyslovení neplatnosti usnesení valné hromady pro rozpor s dobrými mravy. Důsledkem neplatného usnesení valné hromady bude podle \53 odst. 4 ZOK fikce neplatnosti vypořádací smlouvy (v řadě případů se však o fikci jednat nemusí, protože samotná vypořádací smlouva či přinejmenším některá její ujednání mohou být neplatná i ve skutečnosti).

16 Takové úvahy ostatně předkládal již od počátku Havel. Především HAVEL, 2013. O kogentnosti..., op. cit., s. 15.

17 Obdobný př́klady praktické využitelnosti prominutí dluhu LASÁK, Jan. Komentář k ust. \53. In: LASÁK, POKORNÁ, ČÁP, DOLEŽIL a kol., op. cit., s. 449.

$18 \mathrm{~V}$ podstatě se může jednat o podobný zpo̊sob hodnocení, který zná koncernové právo při posouzení, zda byla vyrovnána újma přiměřeným protiplněním nebo jinými výhodami, jak to předvídá $\int 72$ odst. 2 ZOK (ačkoliv zde se vychází z jiných principů). Blíže k jiným způsobům sanace v koncernovém právu např. HAVEL, Bohumil. Komentář k ust. \ 72. In: ŠTENGLOVÁ, HAVEL, CILEČEK, KUHN, ŠUK, op. cit., s. 177 a násl.

19 Zvláště za tuto cennou připomínku, která vzešla z podnětné diskuze po ústním přednesu příspěvku, děkuji B. Havlovi. Při výkladu právního jednání by tak bylo třeba přihlédnout i ke všemu, co právnímu jednání předcházelo, případně k tomu, jaký význam smluvní strany právnímu jednání přikládají (ve smyslu zejména ustanovení \556 odst. 2 OZ). 
Ustanovení \ 2898 OZ tedy není obecně důvodem, proč by mělo být usnesení valné hromady (v případě kapitálových společnostî) neplatné. Důvodem rozporu usnesení s dobrými mravy bude jen určitá výseč případů, na které \2898 OZ dopadá. Zásadně by nemělo stačit, pokud člen orgánu způsobil újmu obchodní korporaci úmyslně nebo hrubou nedbalostí. I v těchto př́padech je myslitelné, že vypořádání úplným prominutím dluhu bude i přesto přiměřené poměrům - a tím i odůvodněné. Zvláště v případě jednání v hrubé nedbalosti může být přiměřenost dána, ačkoliv samotná vypořádací smlouva tomu nenasvědčuje. Naproti tomu úmysl (a především úmysl přímý) bude většinou přiměřenost poměrům vylučovat (a usnesení valné hromady tedy založí rozpor s dobrými mravy). Celkově jsou však důvody pro namítání platnosti usnesení valné hromady užší, než podmínky aplikace \2898 OZ.

Nabízí se dále úvaha, zda $\mathrm{v}$ př́ípadě, kdy vypořádání ani vzdáleně není přiměřené poměrům a vlastně se tedy pojmově vưbec o vypořádání nejedná, není schvalující usnesení valné hromady dokonce $\mathrm{v}$ rozporu se samotným zákonem, který požaduje právě vypořádání. Pokud dále vycházíme z úvahy, že zákon povolal nejvyšší orgán společnosti (valnou hromadu) k tomu, aby schvaloval vypořádací smlouvu, pak je mimo jeho působnost, pokud schvaluje právní jednání, které se jako vypořádací smlouva sice jeví, avšak ve skutečnosti vypořádací smlouvou není. Byt’ se by se v praxi jednalo spíše o př́pady hypotetické, nelze asi vyloučit, že takové chápání působnosti valné hromady by patrně v uvedeném kontextu mohlo směřovat až k úvaze o nicotnosti přijatého usnesení podle $\int 245 \mathrm{OZ}$.

At' již společníci (zejména menšinoví) zvolí jako odůvodnění neplatnosti usnesení valné hromady rozpor s dobrými mravy nebo se zákonem, jedná se o významný nástroj ochrany jejich postavení. Pokud soud prohlásí usnesení valné hromady za neplatné, hledí se i na vypořádací smlouvu jako na neplatnou ${ }^{20}$, a tím pádem se společníkům otevírá možnost domáhat se vypořádání prostřednictvím derivativních žalob. ${ }^{21}$

Věritelé obchodní korporace mají dále možnost domáhat se neúčinnosti vypořádací smlouvy podle $\int 589$ OZ. ${ }^{22}$ Současně je diskuzní vztah vypořádací smlouvy a \159 odst. 3 OZ. Uspořádání vnitřních poměrů v obchodní korporaci by patrně nemělo působit újmu věřitelům. Nemělo by tudíž dojít k zániku ručení podle $\int 159$ odst. 3 OZ. Věřitelé by se proto nadále mohli domáhat splnění svých pohledávek na členech orgánu z titulu ručení. ${ }^{23}$

I v prrípadě, že připustíme možnost vypořádat vzájemné poměry mezi obchodní korporací a členem orgánu i úplným prominutím dluhu, existuje v právu obchodních korporací

\footnotetext{
$20 \mathrm{~K}$ tomu $\int 53$ odst. $4 \mathrm{ZOK}$.

21 Podle $\int 108$ odst. 1 a 2, 157 odst. 1 a 2 a 371 a 372 odst. 1 ZOK.

22 LASÁK, Jan. Komentář k ust. \53. In: LASÁK, POKORNÁ, ČÁP, DOLEŽIL a kol., op. cit., s. 450.

23 Spíše opačné stanovisko zastává Lasák, ačkoliv výslovně pouze k vypořádání formou splátkového kalendáře. Ibid., s. 452.
} 
dostatek možností, jak ochránit třetí osoby i osoby v postavení slabší strany (věritele, menšinové společníky, prípadně samotnou korporaci). Právě ochrana třetích osob a slabší strany (přičemž třetí osoby se budou často nacházet právě v postavení slabší strany, především z důvodu informační asymetrie) představuje obecně limit autonomie vưle smluvních stran. Pokud však jejich ochrana zůstává zachována, není důvodné smluvní svobodu v soukromoprávních vztazích omezovat.

\section{Přehled variant omezení odpovědnosti člena orgánu}

Omezení odpovědnosti člena orgánu (které může mít za následek omezení či vyloučení povinnosti hradit př́padnou újmu) může mít různou podobu a je možné jej učinit v různé časové posloupnosti.

Omezující ustanovení a jejich důsledky lze rozlišit následujícím zpo̊sobem:

1. Omezení odpovědnosti za řádný výkon funkce ${ }^{24}$

Omezení se může vyskytovat ve smlouvě o výkonu funkce, v zakladatelském právním jednání ${ }^{25}$, anebo ve vedlejších individuálních dohodách se členem orgánu. ${ }^{26}$ Možnost takového omezení jednoznačně vylučuje \53 odst. 2 ZOK. Doktrína nicméně připouští i zužující výklad v tom smyslu, že zákaz omezení odpovědnosti za řádný výkon se vztahuje především na fiduciární povinnosti člena orgánu. ${ }^{27}$

Důsledkem porušení zákazu omezit odpovědnost člena orgánu bude nicotnost, což lze odvodit z dikce „se nepríihlíží،

Odpovědnost člena orgánu však nemusí být omezena pouze zúžením odpovědnosti samotné; stejného výsledku lze docílit naopak rozšířením podmínek, za nichž člen orgánu odpovědný nebude. Např́ílad může jít o změnu v předpokladech odpovědnosti, zejména sjednáním př́liš širokého okruhu liberačních důvodů podle 2913 odst. $2 \mathrm{OZ}$, př́padně změnu objektivního principu na princip subjektivní ${ }^{28}$; v tomto

24 Nepřípustné ujednání, které by omezovalo odpovědnosti za řádný výkon funkce, může být například následujícího znění: „člen orgánu bude funkeci vykonávat čestně a s obledem na své schopnosti; smluvni strany výslovně vylučuji pouřití ustanoveni \159 OZ."“

$25 \mathrm{Na}$ zakladatelské právní jednání se nicméně v souladu s jazykovým výkladem ustanovení \53 odst. 2 ZOK vůbec nevztahuje, protože se nejedná o právní jednání korporace, nýbrž právní jednání zakladatelů. Korporace je pouze objektem takového právního jednání, nikoliv subjektem, který jej činí. Nicméně je třeba dovodit, že ustanovení \53 odst. 2 ZOK se vztahuje samozřejmě i na zakladatelská právní jednání, nebot’ pouhý jazykový výklad nedává smysl. K tomu viz LASÁK, Jan. Komentář k ust. \53. In: LASÁK, POKORNÁ, ČÁP, DOLEŽIL a kol., op. cit., s. 447.

26 ŠTENGLOVÁ, Ivana a Bohumil HAVEL. Komentář k ust. \ 53. In: ŠTENGLOVÁ, HAVEL, CILEČEK, KUHN, ŠUK, op. cit., s. 141.

27 PIHERA, 2012, op. cit., s. 142 an.; Dále navazující PIHERA, 2013, op. cit., s. 75.

28 ŠILHÁN, Josef. Právni následky porušeni smlouvy v novém ob̌́anském zákoníku. 1. vyd. Praha: C. H. Beck, 2015, s. 347 . 
směru je však klíčové především posouzení, zda porušení péčí ráádného hospodáře zakládá subjektivní nebo objektivní odpovědnost. ${ }^{29}$

2. Omezení odpovědnosti k náhradě újmy vzniklé přri výkonu funkce předem ${ }^{30}$

Omezení se vztahuje k povinnosti škůdce nahradit újmu. Ujednání o omezení se může vyskytovat v zakladatelském právním jednání, anebo ve smlouvě o výkonu funkce, případně jej obchodní korporace může učinit také jako jednostranné právní jednání.

Limity omezení jsou dány především v \ 2898 OZ. Toto ustanovení zakazuje omezení povinnosti $\mathrm{k}$ náhradě újmy předem $\mathrm{v}$ kvalifikovaných př́padech - zejména pokud se jedná o újmu vzniklou úmyslným zaviněním, anebo v důsledku hrubé nedbalosti, a to pod sankcí nicotnosti. ${ }^{31}$

Ustanovení \2898 OZ je třeba chápat funkčně, resp. z hlediska jeho účelu. ${ }^{32}$ Nevztahuje se totiž zdaleka pouze na vzdání se nebo omezení povinnost k náhradě újmy, které si smluvní strany sjednají výslovně. Naopak se bude vztahovat také na všechna další smluvní ujednání, která se mohou v zakladatelském právním jednání, ve smlouvě o výkonu funkce či v jiných dohodách vyskytovat. V zásadě připadají v úvahu funkční limitace náhrady újmy neprrímým způsobem, anebo př́ípadně jiné nástroje, jejichž systematizaci a podrobný popis představuje Šilhán. ${ }^{33}$

Typicky se bude jednat o sjednání smluvní pokuty v podobě paušalizované náhrady škody. Pokud si smluvní strany sjednají smluvní pokutu, které vylučuje nárok na náhradu škody bez dalšího (tedy pokud si ponechaly dispozitivní režim zákona), je třeba opět aplikovat \2898 OZ. ${ }^{34}$ Omezení nebo vzdání se práva na náhradu újmy předem, pokud jde o sjednání paušalizované náhrady škody v rámci smluvní pokuty, pak ve většině prípadů bude třeba chápat jako vzdání se práva na náhradu újmy předem, př́ičemž bude pravděpodobně zahrnovat i nepř́ípustné vzdání se práva újmy způsobené úmyslně nebo hrubou nedbalostí. Smluvní pokutu k utvrzení povinnosti jednat s péči rrádného hospodáře tak nepochybně sjednat lze (pokud bude

29 Konkrétní závěry by proto předpokládaly hlubší a komplexnější úvahy, které nejsou předmětem tohoto prŕspěvku, ale staly se předmětem celé řady odborných diskuzí. Z poslední doby je všechny shrnuje a vlastní pojetí předkládá Houdek. HOUDEK, Zdeněk. Nad charakterem porušení fiduciárních povinností člena voleného orgánu. Časopis pro právní védu a praxi, Brno: Masarykova univerzita, 2016, č. 4, s. 541 an. DOI: 10.5817/CPVP2016-4-3. Dostupné z: https://journals.muni.cz/cpvp/article/ view/6246

30 Nepřípustné omezení nároku na náhradu újmy by mohlo vypadat například následovně: „Společnost nebude po členovi orgánu požadovat nábradu přpadné újmy, která by v souvislosti s výkonem jebo funkece mobla vaniknout. ", případně: „V př́padech, kdy člen orgánu zpuisobi obchodni korporaci újmu, jejižz výšs préesáhne 500.000,- Kč, je obchodni korporace povinna uzavrít se členem orgánu smlouvu o vájemném vyporádání, na jejímž základè zprostí clena orgánu odpovédnosti ke nábradè újmy. "

31 K úvaze o nicotnosti, ev. neplatnosti v ustanovení \ 2898 viz výše citace v poznámce pod čarou č. 9 aj.

32 Blíže BEZOUŠKA, Petr. Komentář k ust. \ 2898. In: HULMÁK a kol., op. cit., s. 1509.

33 ŠILHÁN, op cit., s. 347 a násl.

34 Blíže BEZOUŠKA, Petr. Komentář k ust. \2898. In: HULMÁK a kol., op. cit., s. 1509. 
dostatečně určitá), avšak současně by smluvní strany měly sjednat také možnost uplatnění náhrady škody pro porušení téže povinnosti (v plné výši, anebo alespoň ve výši přesahující smluvní pokutu).

3. Následné omezení odpovědnost $\mathrm{k}$ náhradě újmy vzniklé při výkonu funkce $\mathrm{Na}$ to, jak obchodní korporace v souladu s $₫ 53$ odst. 3 ZOK naloží se vzniklou újmou, se již žádná omezení (uvedená v předchozích případech) nevztahují. Limity lze hledat v možnosti napadnout usnesení valné hromady, které schválilo vypořádací smlouvu. Rozpor s dobrými mravy, př́padně se zákonem budou zakládat př́edevším prípady, kdy se pojmově vůbec nejedná o vypřádání, a to ani s přihlédnutím k přiměřenému uspořádání poměrů mezi členem orgánu a obchodní korporací.

V úvahu proto přichází vypořádání ve formě částečného nebo úplného prominutí dluhu, vzájemného započtení pohledávek obchodní korporace a člena orgánu či odložení splatnosti pohledávky. Vypořádáním budou také nejrůznější dohody o narovnání. Dále by obchodní korporace mohla vypořádat svoje pohledávky za členem orgánu například vystavením blankosměnky, prípadně by podle okolností (a s ohledem na další ustanovení zákona o obchodních korporacích) součástí vypořádací smlouvy mohlo být výslovné uznání dluhu. Výslovné uznání dluhu mưže být $\mathrm{v}$ některých prípadech praktické, protože pokud vypořádací smlouva spočívá např́iklad v dohodě o započtení, pak z dosavadní judikatury soudu spíše plyne, že započtení není automaticky také uznáním dluhu. ${ }^{35}, 36$

\section{Závěr}

V souvislosti s postavením členů orgánů obchodních korporací je třeba rozlišovat omezení odpovědnosti za rádný výkon funkce a dále omezení odpovědnosti k náhradě újmy předem a následně.

Vzhledem k tomu, že se $\ 2898$ OZ nevztahuje k právním jednáním, kterými se obchodní korporace vzdává práva na náhradu újmy předem, nepředstavuje toto ustanovení limit pro obsah vypořádací smlouvy. Proto si člen orgánu a obchodní korporace mohou mimo jiné ujednat i vypořádání, které spočívá v úplném prominutí dluhu.

Ustanovení \2898 OZ není ani obecným limitem (důvodem) pro dovolání se neplatnosti usnesení valné hromady, která vypořádací smlouvy schválila, pro rozpor s dobrými mravy. Důvody rozporu usnesení s dobrými mravy by měly být užší, než jak je chápe $\ 2898$ OZ, pričemž základním hlediskem by mělo být, zda vypořádací smlouva představuje

35 Např. rozsudek Nejvyššího soudu ze dne 23. 2. 2011, sp. zn. 23 Cdo 3552/2009, usnesení Nejvyššího soudu ze dne 24. 7. 2009, sp. zn. 23 Cdo 3549/2007 a další.

36 Př́pustná limitace nároku na náhradu újmy může znít např́klad takto: „Obchodni korporace se s členem orgánu dohodla na následujicim: íjma ve yýsi 50.000,- KČ́, která obchodni korporaci vznikla v disledku uzavrení smlowvy se spo-

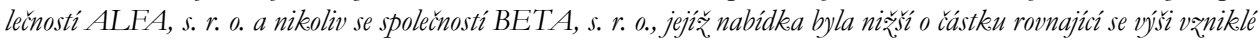
ujmy, se vyporádává tak, že se v₹niklá újma členovi orgánu v plné výši promiji. Smluvni strany se dohodly, že za podminek

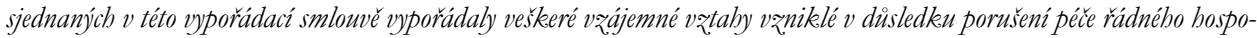
däre člena orgánu spojenébo s roz̧bodnutím o uzavreni nevýhodné smlowvy. " 
vypořádání alespoň v širším slova smyslu (s ohledem na přiměřené uspořádání poměrů). Ekvivalentní a rozumné vypořádání totiž nemusí plynout jen z obsahu vypořádací smlouvy samotné. Odporovat dobrým mravům budou proto především usnesení, která schvalují úmyslné jednání člena orgánu směřující zjevně pouze k poškození obchodní korporace (přičemž se bude jednat především o úmysl přímý). V takovém případě vypořádací smlouva není skutečným vypořádáním, ale spíše zastřeným právním jednáním směřujícím ke zjevnému zneužití práva.

$\mathrm{V}$ těchto případech lze uvažovat také o rozporu usnesení valné hromady se zákonem, nebot' valná hromada vlastně neschvaluje skutečnou vypořádací smlouvu ( $\mathrm{k}$ čemuž je ze zákona oprávněna), ale pouze zastřené právní jednání.

Důsledkem neplatného usnesení valné hromady je fikce neplatnosti vypořádací smlouvy. To otevírá společníkům možnost domáhat se proti členovi orgánu újmy prostřednictvím derivativních žalob.

Věritelé obchodní korporace se mohou domáhat za splnění zákonných předpokladů relativní neúčinnosti vypořádací smlouvy či ručení člena orgánu podle $\int 159$ odst. 3 OZ. Vypořádací smlouva se totiž týká urovnání vnitřních poměrů obchodní korporace, které by nemělo jít $\mathrm{k}$ tíži třetích osob (věřitelů). 